\title{
HIV Protease Inhibitor
}

National Cancer Institute

\section{Source}

National Cancer Institute. HIV Protease Inhibitor. NCI Thesaurus. Code C97366.

A protease inhibitor that is designed to target the human immunodeficiency virus (HIV) protease while sparing other host cell proteases. HIV protease mediates the cleavage of viral Gag, Gag-Pol and Nef precursor polypeptides into their mature proteins. Inhibition of HIV protease results in production of noninfectious viral particles. 